\title{
Geomorphological evolution of coastal landslides in Malta: integration of terrestrial and marine datasets
}

\author{
Mauro Soldati, Mariacristina Prampolini, Vittoria Vandelli \\ University of Modena and Reggio Emilia \\ Department of Chemical and Geological Sciences \\ Modena, Italy
}

\begin{abstract}
The paper shows the main results of multidisciplinary research carried out in the Island of Malta aiming at the integration of terrestrial and marine datasets. Identification, mapping, monitoring and dating of landsides, including submerged ones, have enabled to define a time frame for the development of landslides and to reconstruct the geomorphological evolution of the investigated areas. This has provided useful means for landslide susceptibility and hazard mapping, which is crucial for north-west coast of Malta.
\end{abstract}

Keywords - coastal geomorphology; landslides; dating; Malta; Mediterranean Sea

\section{INTRODUCTION}

Coastal areas are often densely populated and heavily urbanized mainly due to tourist and recreational activities. For this reason recognition of active coastal processes and the understanding of past and present geomorphological evolution is crucial in hazard assessment and risk mitigation.

This paper shows the results of research carried out within the framework of projects funded by the EUR-OPA Major Hazards Agreement (Council of Europe) aiming at providing national and regional administrations with methodologies for geomorphological hazard assessment in coastal areas. Integrated geomorphological mapping of emerged and submerged areas of the north-west coast of the Island of Malta (central Mediterranean Sea) was carried out, with special attention to gravity-induced landforms and processes, in order to achieve baseline datasets to be used for landslide susceptibility mapping and subsequently for hazard and risk assessments.

\section{GeOlOGICAL AND GEOMORFOLOGICAL SETting}

From a geological viewpoint, the Island of Malta is characterized by a marine sedimentary succession made up of different lithotypes mainly ascribable to limestones, marls and clays ranging in age from the Upper Oligocene to the Upper Miocene [1]. In the north-western sector of Malta, the outcropping rocks mainly belong to the Blue Clay Formation, consisting of grey soft marls, and the overlying Upper Coralline Limestone Formation, consisting of grey hard limestones (Fig. 1). The Blue Clays outcrop in correspondence of slopes locally terraced inland and reaching the sea along a widespread coastal stretch.
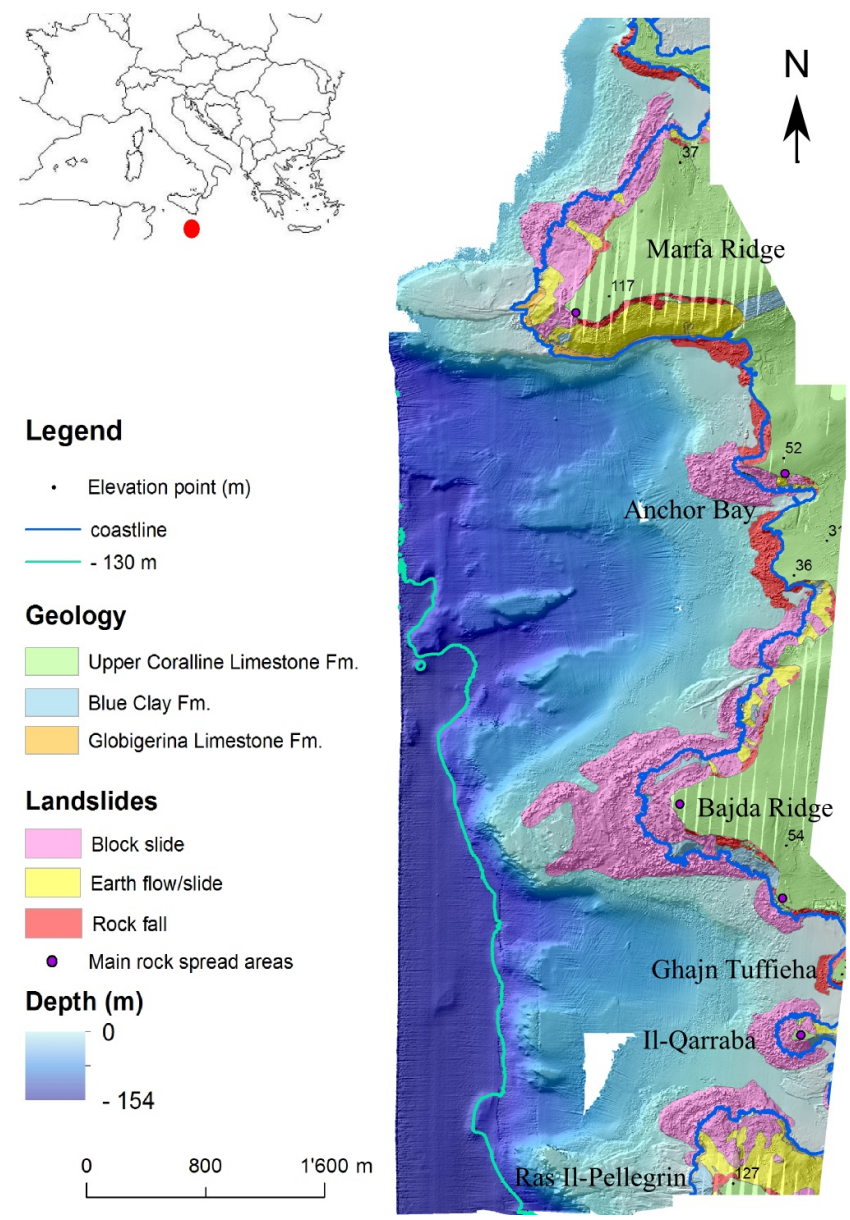

Fig. 1. Location of the Maltese archipelago and distribution of landslides along the NW coast of the Island of Malta.

From a tectonic perspective, a WSW-ENE oriented fault system determines a horst-and-graben structure deeply influencing the topography and the coastal 
morphology of the investigated area. The tectonic setting and the overlapping of hard and fragile limestones over visco-plastic terrains (marls and clays) favours the development of impressive rock spreading and block sliding phenomena which are widespread in particular at Ghajn Tuffieha Bay (Fig. 2), Ras Il-Wahx and Marfa Ridge.

Block slides are the most diffuse type of landslide along the north-west coast of Malta and they characterize both the emerged and submerged geomorphological landscape. Block-slide accumulations are associated with rock falls and rock topples occurring at the edges of the limestone plateaus, whose detachment is favored by persistent fissures and cracks of tectonic origin enlarged by rock spreading [2, 3]. In addition, earth flows and earth slides are frequent in the clayey slopes, as well as gully erosion.

\section{EMERGED AND SUBMERGED LANDSLIDE FEATURES}

In the first research stages, emerged coastal landslides were identified, mapped [4] and monitored [3] along the north-west coast of the Island of Malta. Further on, the research moved underwater to investigate the continental shelf. A multibeam survey coupled with an airborne bathymetric LiDAR survey were carried out allowing to produce a continuous high-resolution (2 m) Digital Elevation Model (DEM) of coastal and submarine areas.

The coupling between terrestrial and marine datasets showed that mass-movement deposits have a clear continuity above and below the sea level (Fig. 3). In correspondence of coastal stretches affected by block
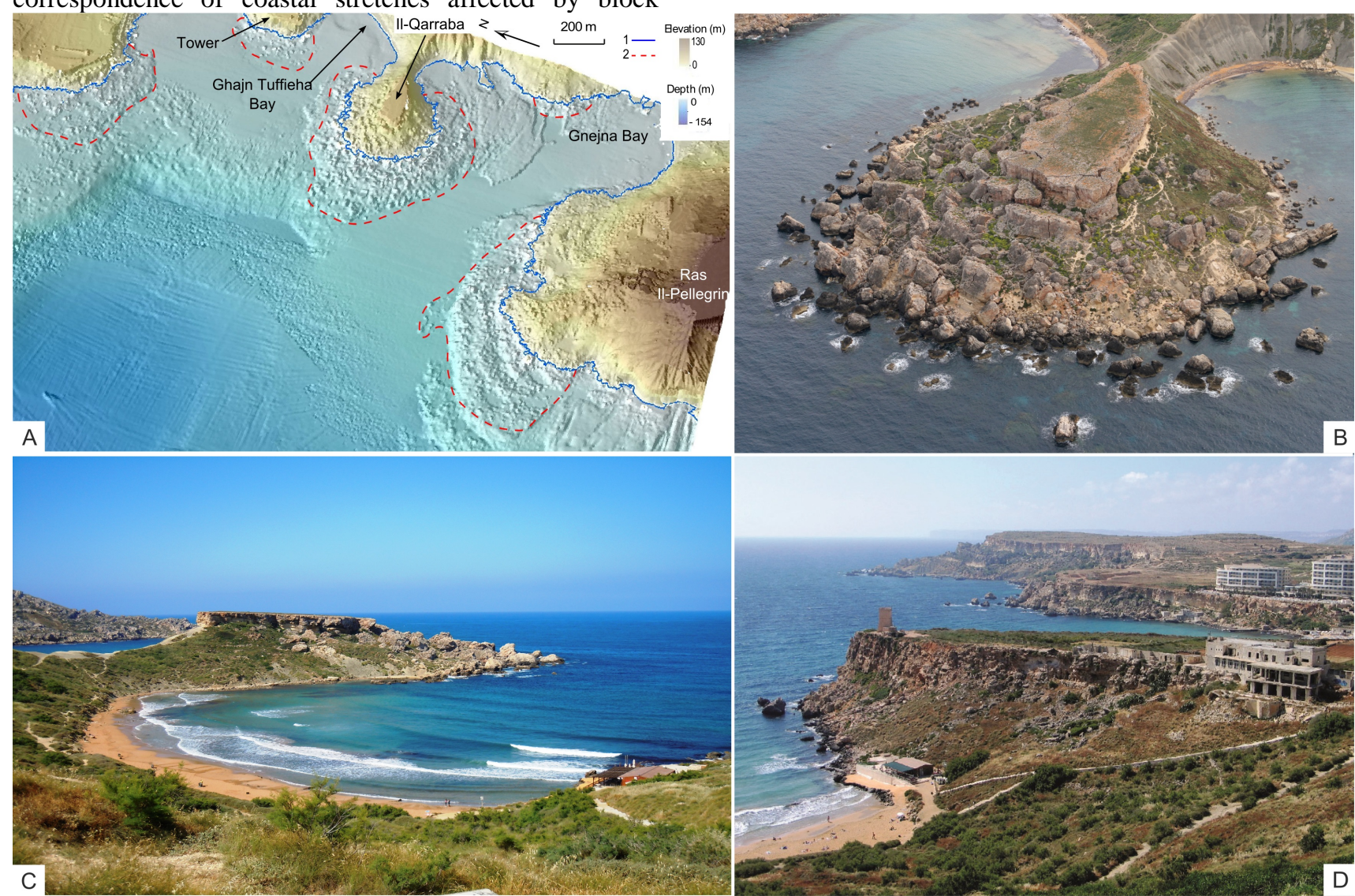

Fig. 2. Coastal stretch between Ghajn Tuffieha Bay and Ras Il-Pellegrin promontory, north-west coast of Malta. A) DTM of the area and surrounding seafloor; 1) present coastline; 2) outline of the submarine landslide deposit; B) Aerial view of Il-Qarraba plateau affected by block slides; C) IlQarraba peninsula and Ghajn Tuffieha Bay seen from the north; D) Ghajn Tuffieha northern side seen from the south 
As a result of CRE dating, a sample collected close to the limestone cliff edge at Anchor Bay provided a date of ca. $21 \mathrm{kyr}$, which was the oldest date achieved for the north-west coast. It should be noted that time the sea level was about $130 \mathrm{~m}$ lower than at present which means that the detachment occurred in complete subaerial conditions. According to other dating, successive displacements took place up to $7.4 \mathrm{kyr}$ ago, that is in a period when the sea level had already reached the landslide accumulations, possibly influencing their development. For further information on landslide dating along the north-west coast of Malta, see [8].

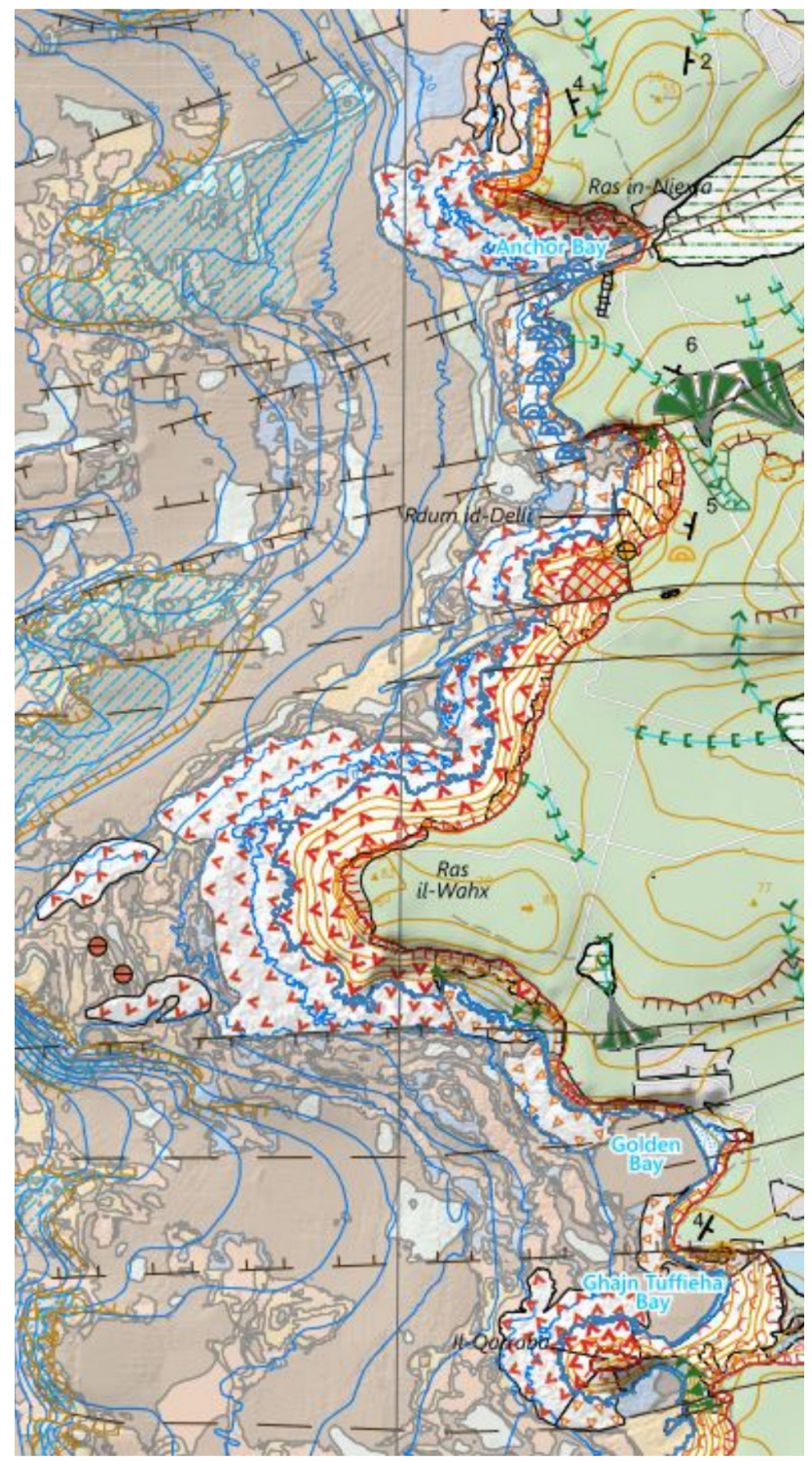

Fig. 3. Sketch of the geomorphological map of emerged and submerged areas of north-west Malta, from Anchor Bay to the north and Il-Qarraba promontory to the south. The bold blue line corresponds to the present coastline. Modified after [6].

\section{GEOMORPHOLOGICAL EVOLUTION}

Most of the geomorphological features identified on the seafloor - including landslide deposits - are terrestrial in origin and were emerged during the Last Glacial Maximum (LGM), when the sea level was about $130 \mathrm{~m}$ lower than at present $[9,10]$. The CRE dating confirmed that also the block slides, which largely characterize the north-west coast of the Island of Malta, developed in subaerial conditions, whilst their accumulations were partially submerged and hidden by the sea during by the post-glacial marine transgression [8].

The block slides possibly sped up when the sea level reached the landslide deposits during post-glacial sea level rise. CRE dating showed that older detachment events are located more inland. Therefore, the block-slide deposits observable nowadays, both on land and on the seafloor, may have developed as a result of a first-time failure involving large portions of the slopes. Secondary movements are likely to have occurred later on in time also under the influence of the sea action, as a consequence of progressive sea level rise. Investigations on mass movement kinematics are in progress aiming at modelling block-slide evolution through time.

\section{CONCLUSIONS}

The integration of terrestrial and submarine datasets represents a novel approach for the reconstruction of the geomorphological evolution of coastal areas, which is crucial in Mediterranean areas also in consideration of the ongoing climatic changes. The knowledge of spatial and temporal distribution of landslides has provided the means for correct and reliable susceptibility and hazard assessments, which are of paramount importance in tourist areas, such as the north-west coast of Malta $[11,12]$.

\section{ACKNOWLEDGMENTS}

This research was part of the Projects "Coupling terrestrial and marine datasets for coastal hazard assessment \& risk reduction in changing environments" (2014-15) and "Developing geomorphological mapping skills and datasets in anticipation of subsequent susceptibility, vulnerability, hazard and risk mapping" (2016-17) funded by the EUR-OPA Major Hazards Agreement of the Council of Europe (responsible: M. Soldati). We acknowledge the contribution of Timothy Barrows in CRE dating at the University of Exeter.

\section{REFERENCES}

[1] N. Baldassini and A. Di Stefano, "Stratigraphic features of the Maltese Archipelago: a synthesis”, Natural Hazards, vol. 86, no. 2, pp. 203-231, 2017.

[2] S. Devoto, E. Forte, M. Mantovani, A. Mocnik, A. Pasuto, D. Piacentini, and M. Soldati, "Integrated monitoring of lateral spreading phenomena along the north-west coast of the Island of Malta”, in Landslide Science and Practice, Vol. 2, C. Margottini, P. Canuti, and K. Sassa, Eds. Springer-Verlag, Berlin Heidelberg, 2013, pp. 235-241.

[3] M. Mantovani, S. Devoto, E. Forte, A. Mocnik, A. Pasuto, D. Piacentini, and M. Soldati, "A multidisciplinary approach for rock spreading and block sliding investigation in the north-western coast of Malta”, Landslides, vol. 10, no. 5, pp. 611-622, 2013.

[4] S. Devoto, S. Biolchi, V. M. Bruschi, S. Furlani, M. Mantovani, D. Piacentini, A. Pasuto, and M. Soldati, M., "Geomorphological map of the NW Coast of the Island of Malta (Mediterranean Sea)", Journal of Maps, vol. 8, no. 1, pp. 33-40, 2012.

[5] F. Foglini, M. Prampolini, A. Micallef, L. Angeletti, V. Vandelli, A. Deidun, M. Soldati, and M. Taviani, "Late Quaternary coastal landscape morphology and evolution of the Maltese Islands (Mediterranean Sea) reconstructed from high resolution seafloor data”, in Geology and Archaeology: Submerged landscapes of the continental shelf, J. Harff, G. Bailey, and F. Lüth, Eds. Geological Society, London, Special Publications, 2016, 411, pp. 77-95.

[6] M. Prampolini, F. Foglini, S. Biolchi, S. Devoto, S. Angelini, and M. Soldati, "Integrated geomorphological map of emerged and submerged areas of northern Malta and Comino (central Mediterranean Sea)”, Journal of Maps, 2017, in press. 
[7] S. Devoto, M. Mantovani, A. Pasuto, D. Piacentini, and M. Soldati "Long-term monitorning to support landslide inventory maps: the case of north-western coast of the Island of Malta”, in Engineering Geology for Society and Territory, Vol. 2, G. Lollino, D. Giordan, G.B. Crosta, J. Corominas, R. Azzam, J. Wasowski, and N. Sciarra, Eds. Springer International Publishing, Switzerland, 2015, pp. 1307-1310

[8] M. Soldati, T.T. Barrows, and M. Prampolini, "Landslides and sea level changes: evidence of the complex geomorphologica evolution of the NW coast of Malta from exposure dating using cosmogenic nuclides”, Rendiconti Online della Società Geologica Italiana, vol. 40, no. 1, p. 368, 2016.

[9] K. Lambeck, F. Antonioli, M. Anzidei, L. Ferranti, G. Leoni, and S. Silenzi, "Sea level change along the Italian coasts during Holocene and prediction for the future”, Quaternary International, vol. 232, pp. 250-257, 2011
[10] A. Micallef, F. Foglini, T. Le Bas, L. Angeletti, V. Maselli, A. Pasuto, and M. Taviani, "The submerged paleolandscape of the Maltese Islands: Morphology evolution and relation to Quaternary environmental change”, Marine Geology, vol. 335, pp. 129-147, 2013.

[11] D. Piacentini, S. Devoto, M. Mantovani, A. Pasuto, M. Prampolini, and M. Soldati "Landslide susceptibility modeling assisted by Persistent Scatterers Interferometry (PSI): an example from the northwestern coast of Malta”, Natural Hazards, vol. 78, no. 1, pp. 681-697, 2015

[12] M. Soldati, O. Maquaire, J.L. Zezere, D. Piacentini, and C. Lissak, "Coastline at Risk: Methods for Multi-Hazard Assessment", Journal of Coastal Research, Special Issue No. 61, pp. 335-339, 2011. 